\title{
Ketepatan Kode Diagnosis Sistem Sirkulasi di Klinik Jantung RSUD Wates
}

\author{
Heri Hernawan ${ }^{1}$, Kori Puspita Ningsih ${ }^{2}$, Winarsih ${ }^{3}$ \\ Dosen Program Medis Perekam Medis dan Informasi Kesehatan (D-3) \\ STIKES Jenderal Achmad Yani Yogyakarta ${ }^{1,2}$ \\ Mahasiswa Program Medis Perekam Medis dan Informasi Kesehatan (D-3) \\ STIKES Jenderal Achmad Yani Yogyakarta ${ }^{3}$ \\ Jalan Ringroad Barat, Meijing Kidul, Kec. Gamping, Kab. Sleman \\ Yogyakarta 55294 \\ herihernawan.jp@gmail.com¹ ${ }^{\text {, puspitakori@gmail.com², Sayawinarsih@gmail.com³ }}$
}

\begin{abstract}
ABSTRAK
Latar Belakang: Ketepatan kode diagnosa sangat penting untuk sarana pelayanan kesehatan di masyarakat. Berdasarkan studi pendahuluan yang dilakukan di Instalasi Rekam Medis RSUD Wates, dari jumlah 30 berkas rekam medis pasien rawat jalan dengan kasus Kardiovaskuler menunjukan bahwa $86,67 \%$ kode diagnosis yang tidak tepat sesuai dengan ICD-10 dan 13,33\% kode diagnosis yang tepat sesuai dengan ICD-10.

Tujuan: Mengetahui pelaksanaan pengisian kode peyakit, presentase ketepatan kode penyakit dan fator penyebab ketidaktepatan kode sistem sirkulasi di klinik jantung RSUD Wates

Metodologi Penelitian: Jenis penelitian yang digunakan yaitu deskriptif dengan pendekatan kualitatif kuantitatif, dengan rancangan cross sectional. Populasi penelitian 2189 berkas rekam medis kasus sistem sirkulasi di klinik jantung periode januari-maret 2017, teknik pemilihan sampel dengan random sampling, jumlah sampel penelitian sebesar 98 berkas medis sistem sirkulasi di klinik jantung. Teknik pengumpulan data dengan observasi, wawancara dan studi dokumentasi.

Hasil: Tingkat Ketepatan kode diagnosa sistem sirkulasi di RSUD Wates dari total sampel yang diambil yaitu 98 berkas rekam medis, dari yang tertinggi secara berturut-turut adalah Kategori B 49\% (48 dari 48 berkas rekam medis), kategori C 27\% (26 dari 98 berkas rekam medis), kategori A 18\% (18 dari 98 berkas rekam medis) dan 6\% (6 dari 98 berkas rekam medis).

Kesimpulan: pengodean tidak dilakukan oleh petugas rekam medis, tingkat ketepatan kode diagnosa pasien rawat jalan sistem sirkulasi masih tidak baik, belum adanya SOP Pengodean pasien rawat jalan dan masih kurangnya buku ICD-10 untuk melakukan pengodean.
\end{abstract}

\section{ABSTRACT}

Background: The accuracy of diagnostic codes is very important for health care facilities in the community. Based on a preliminary study conducted at the Medical Record Installation of Wates Hospital, out of 30 records of outpatient medical records with Cardiovascular cases showed that $86.67 \%$ of diagnostic codes were not accurately consistent with ICD-10 and 13.33\% Appropriate diagnosis codes according to ICD-10.

Objectives: To know the accuracy coding diagnosis, presentation of accuracy coding diagnosis, and factor causing of inaccuracy of coding diagnosis circulation system at Cardiac Clinic of Wates Hospital

Method: Research used is descriptive with qualitative quantitative approach, with cross sectional design. Population research 2189 medical records cases circulation system at cardiac clinic period January until March 2017. Technique sampling used random sampling, total sampling 98 medical records cases circulation system at cardiac clinic. Technique data used observation, interview and study documentation.

Result: Level of accuracy of circulation system diagnostic code in Wates Hospital of total samples taken are 98 medical records file, from the highest respectively is Category B 49\% (48 of 48 medical record files), C category 27\% (26 from 98 medical record files), category A 18\% (18 out of 98 medical record files) and $6 \%$ (6 of 98 medical record files).

Conclusions: the coding is not done by the medical record officer, the accuracy of the outpatient diagnostic code of the circulatory system is still not good, the absence of SOP Coding outpatients and still lack of ICD-10 books to do the coding.

Keywords: Inaccuracy, Diagnosis Code, Circulation System 


\section{PENDAHULUAN}

Rekam medis adalah berkas yang berisi catatan dan dokumen tentang identitas, anamnesa, diagnosis, tindakan dan pelayanan penunjang yang diberikan kepada pasien selama pasien mendapatkan pelayanan di rumah sakit, baik di unit rawat jalan, rawat inap, serta gawat darurat (Ismainar, 2015). Klasifikasi Diagnosis adalah penyeragaman penyakitpenyakit dan prosedur-prosedur yang sejenis ke dalam suatu grup nomor kode penyakit dan tindakan yang sejenis. International Statistical Classification of Diseases and Related HealthProblem (ICD) adalah sistem klasifikasi yang komprehensif dan diakui secara internasional. Kualitas hasil pengodean bergantung pada kelengkapan diagnosis, keterbacaan tulisan dokter, serta profesionalisme antara dokter dengan petugas coder. Diagnosis adalah penentuan sifat penyakit atau membedakan satu penyakit dengan penyakit yang lainnya berdasarkan tanda, gejala, dan pemeriksaan laboratorium selama kehidupan (WHO, 2010). RSUD Wates merupakan rumah sakit tipe kelas B Pendidikan. RSUD Wates merupakan salah satu pusat pelayanan kesehatan yang terletak di daerah Wates Kulon Progo. Berdasarkan sampling yang di ambil pada saat studi pendahuluan sebanyak 30 berkas pasien rawat jalan di RSUD Wates terdapat $86,67 \%$ kode diagnosis yang tidak tepat sesuai dengan ICD-10 dan 13,33\% kode diagnosis yang tepat sesuai dengan ICD-10. Terdapat permasalahan pengkodean diagnosis pasien rawat jalan yang dilakukan perawat masing-masing klinik dengan cara mengentry kedalam SIRS, kemudian keluar secara otomatis dan tidak dapat di validasi oleh petugas rekam medis.

\section{BAHAN DAN CARA PENELITIAN}

Jenis penelitian ini menggunakan deskriptif. (4) dengan pendekatan kualitatif. (5) menggubakan rancangan cross sectional. penelitian dilaksanakan di Instalasi Rekam Medis RSUD Wates.
Popuasi penelitian sebanyak 2189 berkas rekam medis kasus sistem sirkulasi di klinik jantung periode januari-maret 2017, teknik pemilihan sampel dengan random sampling, Total sampel yang diambil yaitu 98 berkas rekam medis kasus sistem sirkulasi klinik jantung. Teknik pengumpulan data dalam penelitian ini adalah pengamatan (observasi), wawancara, dan studi dokumentasi. Instrumen pengumpulan data menggunakan chek list observasi, pedoman wawancara, buku dan alat tulis, recorder dan kamera .

Metode pengolahan data kualitatif dengan tahap: editing, coding, data entry, dan cleaning. Kemudian data di olah dengan langkah-langkah data reduction, data display, dan verification. Sedangkan metopde pengaolahan data kuantitatif menggunakan analisis univariate dengan melihat persentase tiap variable penelitian.

\section{HASIL DAN PEMBAHASAN}

\section{Proses Pengodean Diagnosis Sistem} Sirkulasi

\section{a. Sistem Pengodean}

Alur Pengodean Diagnosis Pasien Rawat Jalan

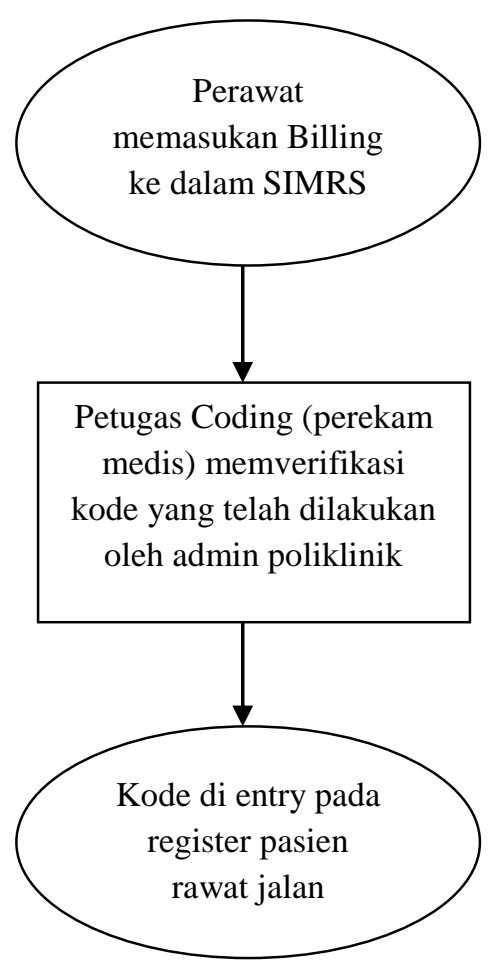


Sumber: Hasil Observasi di Instalasi Rekam Medis

Berdasarkan studi dokumentasi pada pedoman perorganisasian instalasi rekam medis tentang uraian tugas pada Penanggung Jawab Unit Pengolahan Berkas, Pengolahan Data dan Pelaporan salah satunya adalah pelaksanaan pengodean yaitu dilaksanakan oleh petugas rekam medis. Berdasarkan hasil studi dokumentasi di RSUD Wates sudah terdapat SOP Pengodean Nomor MKI/449.1/06/2015 tentang Pemberian Kode Penyakit dan Tindakan (Coding) Rekam Medis Rawat Inap, dengan isi sebagai berikut: 1) Status yang telah dirakit/asembling diterima oleh petugas koding; 2) Petugas menuliskan kode penyakit berdasarkan buku ICD-X dan kode tindakan berdasarkan buku ICD-IX $\mathrm{CM}$; 3) Seluruh diagnosa penyakit, baik itu diagnosa utama dan diagnosa sekunder dilakukan pengodean; 4)Petugas mulai mencari kode penyakit pada buku indeks ICD-X Vol.III; 5) Untuk mengecek kebenaran kode penyakit, petugas dapat mengecek pada buku ICD-X Vol.I; 6) Untuk kode tindakan, petugas dapat mencari kode tindakan pada buku ICD-IX CM; 7) Petugas mencatat rekam medis yang memiliki tindakan pada buku kendali rekam medis dengan tindakan; 8) Status rekam medis rawat inap yang telah dikode dengan lengkap diserahkan kebagian indeksing. Namun untuk SOP Pelaksanaan pengodean pasien rawat jalan masih belum terdapat SOP untuk melakukan pengodean kode diagnosa.

Standar Operasional Prosedur (SOP) pada dasarnya adalah pedoman yang berisi prosedur operasional standar yang ada di dalam suatu organisasi yang digunakan untuk memastikan bahwa setiap keputusan, langkah, tau tindakan yang digunakan fasilitas pemprosesan yang dilaksanakan oleh orang-orang di organisasi telah berjalan efektif, kosisten standard dan sistematis
(Tambuanan, 2013). Menurut KARS (2012) pada standar akreditasi MKI.13 bahwa harus ada kebijakan, pedoman, atau SOP untuk mengatur pengodean. Bukti dokumentasi tersebut meliputi Kode diagnosis, kode prosedur/tindakan, definisi yang digunakan, simbol (termasuk yang tidak boleh digunakan), dan singkatan (termasuk yang tidak boleh digunakan).

\section{b. Sarana Prasarana}

Berdasarkan hasil dari observasi yang dilakukan sarana yang digunakan untuk melakukan pengodean kode diagnosis pasien rawat jalan yang dilakukan perawat yaitu menggunakan Komputer untuk mengentry diagnosa pasien, dan buku bantu untuk membantu petugas melakukan pengodean maupun pengentryan diagnosa. Namun untuk buku bantu yang digunakan tidak dilakukan pengesahan karena menurut keterangan bahwa buku bantu tersebut hanya catatan kecil yang dibuat oleh masing-masing petugas.

ICD-10 adalah pedoman untuk merekam dan memberi kode penyakit, disertai dengan materi baru yang berupa aspek praktis penggunaan klasifikasi. ICD bertujuan untuk mendapat rekaman yang sistematik, dapat melakukan analisis, intepretasi, serta digunakan untuk membandingkan data morbiditas dan mortalitas dari negara yang berbeda atau antar wilayah yang berbeda (WHO, 2010).

Sarana prasarana yang mendukung kelancaran kodefikasidibutuhkan ICD 10, ICD 9CM, aplikasi ICD, computer, printer, internet, kamus kedokteran dan kamus bahasa inggris (Pela, 2017). Dalam pelaksanaan pelayanan di rumah sakit SIMRS juga berperan penting bagi mutu pelayanan, antara lain sebagai: aspek administrasi, aspek hukum, aspek keuangan, aspek riset dan edukasi dan aspek dokumentasi (Aditama, 2012).

\section{c. SDM Pengodean}


Berdasarkan hasil observasi yang dilakukan di RSUD Wates Sumber daya manusia petugas pengodean di Instalasi Rekam Medis RSUD Wates yaitu berjumlah 2 orang yakni satu rawat jalan dan satu rawat inap. Namun untuk pelaksanaannya, pengentryan kode diagnosa pasien rawat jalan dilakukan oleh perawat dengan cara mengentry diagnosa yang telah ditetapkan oleh dokter kedalam SIMRS yang ada dikomputer masingmasing ruangan poliklinik sehingga muncul kode diagnosa secara otomatis Menurut PERMENKES No.55/MenKes/PER/III/2013 pasal 13 dalam pelaksanaan pekerjaannya perekam medis mempunyai kewenangan sesuai dengan kualifikasi pendidikan seorang ahli madya perekam medis antara lain melaksanakan sistem klasifikasi klinis dan kodefikasi penyakit yang berkaitan dengan kesehatan dan tindakan medis sesuai terminologi medis yang benar, melaksanakan sistem pelaporan dalam bentuk informasi kegiatan pelayanan kesehatan dan melaksanakan evaluasi kelengkapan isi diagnosis dan tindakan sebagai ketepatan pengodean. Kompetensi perekam medis yaitu perekam medis harus mampu melakukan tugas dalam meberikan pelayanan rekam medis dan informasi kesehatan yang bermutu tinggi dengan memperhatikan beberapa kompetnsi, salah satunya adalah klasifikasi dan kodefikasi penyakit (Rustiyanto, 2009).

2. Tingkat Ketepatan Kode Diagnosis Sistem Sirkulasi Klinik Jantung di RSUD Wates

Berdasarkan observasi dengan melihat laporan register pasien rawat jalan dan berkas rekam medis kasus sistem sirkulasi di RSUD Wates dengan menggunakan lembar ceklist yang dilihat pada formulir pasien rawat jalan ditemukan beberapa kode yang tidak tepat pada kasus sistem sirkulasi.
Pengodean adalah pemberian penetapan kode dengan menggunakan huruf atau angka atau kombinasi huruf dalam angka yang mewakili komponen data. Kegiatan coding dilakukan setelah perakitan dan analisis berkas (Hatta, 2012). Sehubungan dengan ketepatan kode diagnosis dari 98 berkas rekam medis kasus sistem sirkulasi didapat hasil sebagai berikut:

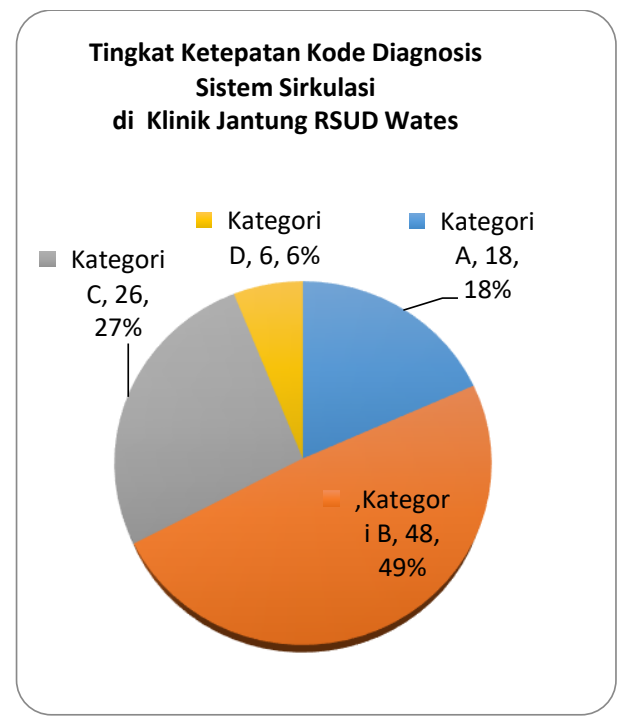

Dari grafik diatas dapat diketahui presentase ketepatan kode diagnose dari 98 berkas rekam medis yang sudah di observasi didapatkan 6\% kode pada register rawat jalan tidak dikode (kategori D) sedangkan 49\% kode diagnosa ditulis kurang lengkap (kurang karakter keempat) (Kategori B).. Danik dan Nuryati (2014) menyatakan bahwa penulisan diagnosis antara berkas rekam medis dengan EHR harus sesuai karena akan mempengaruhi kualitas dan mutu pelayanan kesehatan yang diberikan oleh rumah sakit terhadap pasien serta mempengaruhi proses pengambilan kebijakan oleh rumah sakit

Dilihat dari tabel diatas ketepatan kode diagnosa hanya sebesar $18 \%$ (Kategori A). Menurut Octaria (2012) ketepatan dan kecepatan terhadap pengkodean penyakit dimonitor oleh reliability (kehandalan), validity (keakuratan) dan completeness (kelengkapan) dengan meningkatkan ketepatan dan kecepatan pengkodingan penyakit menghindari 
Tabel 4.1. Hasil Perhitungan Ketepatan Kode

\begin{tabular}{llc}
\hline Hasil & $\begin{array}{l}\text { Jumlah } \\
\text { Berkas }\end{array}$ & Prosentase \\
\hline $\begin{array}{l}\text { Kategori A } \\
\text { Jika kode diagnosa } \\
\text { ditulis tepat sesuai }\end{array}$ & 18 & $18 \%$ \\
dengan ICD-10 & & \\
Kategori B & & \\
Jika kode diagnosa & & \\
ditulis kurang & 48 & \\
lengkap (kurang & & \\
karakter keempat) \\
Kategori C \\
Jika kode diagnosa \\
ditulis berbeda \\
dengan kode yang
\end{tabular}

3. Faktor Penyebab Ketidaktepatan Kode Diagnosis Sitem Sirkulasi Klinik Jantung di RSUD Wates Triwulan I Tahun 2017

\section{a. Faktor Sistem}

Dalam pelaksanaan pengodean ternyata petugas masih belum mengetahui ada atau tidaknya sistem kebijakan, SOP maupun pedoman yang mengatur pelaksanaan pengodean kode diagnosis pasien rawat jalan salah satunya adalah kode diagnosa pada kasus sistem sirkulasi di RSUD Wates.

\section{b. Faktor Sarana Prasarana}

Berdasarkan hasil observasi yang dilakukan sarana yang digunakan dalam pengodean yang dilakukan yaitu buku ICD-10, SIMRS pada komputer, dan buku bantu namun pada pelaksanaan SIMRS yang digunakan sering terjadi eror, baik itu dari sistemnya maupun dari gangguan listrik yang ada di RSUD Wates, untuk hasil pengodean yang dilakukan oleh perawat pada SIMRS tidak dapat diverifikasi oleh petugas rekam medis. Di RSUD Wates penulisan diagnosis pada kasus sistem sirkulasi yang menggunakan singkatan, dan terdapat sudah terdapat buku singkatan. KARS (2012), pada standar MKI.13 Rumah Sakit menggunakan standar kode diagnosa, kode prosedur/tindakan, simbol, singkatan, dan definisi. Maksud dan tujuan MKI. 13 yakni Standarisasi terminologi, definisi, vocabulary (kosa kata) dan penamaan (nomenklatur) memfasilitasi perbandingan data dan informasi di dalam maupun antar rumah sakit.

\section{c. Faktor SDM}

Berdasarkan hasil observasi yang dilakukan pengkodean untuk pasien rawat jalan di RSUD Wates dilakukan oleh masing-masing perawat poli dengan mengentry diagnosa yang diberikan oleh dokter seperti kasus sistem sirkulasi di poli jantung yang dilakukan oleh perawat dan bukan dilakukan oleh petugas coding dari bagian unit rekam medis, karena petugas pengodean di unit rekam medis hanya 2 orang dan menurut salah satu sumber untuk petugas pengodean memang masih dirasa kurang, tetapi sudah ada rencana untuk penambahan petugas.

\section{KESIMPULAN}

Pengodean diagnosis pada kasus sistem sirkulasi di klinik jantung RSUD Wates tidak dilakukan oleh petugas rekam medis, namun untuk kode diagnosa yang telah diberikan oleh dokter setelah selesai pelayanan di entry kedalam sistem aplikasi yang ada di komputer oleh admin perawat di poliklinik masing-masing sehingga kode diagnosa muncul secara otomatis, Tingkat ketepatan kode diagnosa pada kasus sistem sirkulasi klinik jantung di RSUD Wates masih belum baik karena tingkat ketepatan kode yang sesuai dengan ICD-10 hanya mencapai 18\% (18 dari 98 berkas rekam medis), Faktor penyebab ketidaktepatan kode diagnosa sistem sirkulasi klinik jantung di RSUD Wates dari, faktor sistem yaitu belum ada SOP Pengodean pasien rawat jalan, dari faktor sarana prasarana yaitu sering terjadi eror pada SIMRS yang digunakan oleh petugas, tidak terdapat aplikasi untuk validasi pada SIMRS, ICD10 yang terbatas jumlahnya, dan diagnosis 
pasien tidak terbaca, kemudian dari faktor SDM pengodean tidak dilakukan oleh petugas rekam medis namun diagnosa dientry oleh perawat atau admin yang ada di poliklinik masing-masing kedalam SIMRS sehingga akan muncul kode diagnosa secara otomatis.

\section{SARAN}

Sebaiknya pengodean diagnosis pasien rawat jalan di RSUD Wates dilakukan oleh petugas yang berkompeten yaitu petugas rekam medis sesuai dengan kualifikasi pendidikan seorang perekam medis, Sebaiknya pengodean kode diagnosa tetap dilaksanakan oleh petugas rekam medis agar tingkat ketepatan kode diagnosa bisa lebih baik lagi, Sebaiknya terdapat SOP Pengodean rawat jalan, untuk menyeragamkan prosedur pengodean diagnosis dan dilakukan pengadaan buku ICD-10 sesuai dengan kebutuhan petugas pengodean.

\section{DAFTAR PUSTAKA}

Aditama, Tjandra Yoga. 2012. Manajemen Administrasi Rumah Sakit. Jakarta: Universitas Indonesia.

Atmoko, Tjipto. 2011. Standar Operasional Prosedur (SOP) dan Akuntabilitas Kinerja Instansi Pemerintah. Jakarta

Danik dan Nuryati. 2014. Kesesuaian Diagnosis pada Berkas Rekam Medis dan HER Pasien Instalasi Gawat Darurat. Journal Karya Tulis Ilmiah. APTIRMIK: Volume 3 Nomor 1.

Dorlan, W.A. Newman. 2012. Kamus Kedokteran Dorland; Edisi 28. Buku Kedokteran EGC, Jakarta.

Hatta, Gemala. 2012. Pedoman Manajemen Informasi Kesehatan Di Sarana Pelayanan Kesehatan. Jakarta: Universitas Indoenesia

Ismainar, H. 2015. Manajemen Unit Kerja. Budi Utama. Yogyakarta.

KARS. 2012. Standar Akreditasi Rumah Sakit, Kerjasama Direktorat Jenderal Bina Upaya Kesehatan Kementerian Kesehatan Republik Indonesia dengan Komisi Akreditasi Rumah Sakit (KARS), Jakarta.

Notoatmodjo, Soekidjo. 2010. Metodologi Penelitian Kesehatan, Rineka Cipta, Jakarta.

Octaria H. 2015. Peningkatan Kualitas Pengkodean Pada Ketepatan dan kecepatan Pengkodean Penyakit Untuk penagihan Klaim BPJS RSUD Petala Bumi pekanbaru tahun 2015. Tesis. STIKES Hangtuah Pekanbaru

Pela, TH et all. 2017. Ketepatan Kode Kombinasi Hypertensi Pada Penyakit Jantung dan Penyakit Ginjal Berdasarkan ICD 10 Di Rumah Sakit Ibnu SIna Pekanbaru. Jurnal Manajemen Informasi Kesehatan Indonesia: Vol 5 Hal 53-59

Permenkes RI No. 55/MENKES/PER/III/2013, Penyelenggaraan Pekerjaan Perekam Medis, Republik Indonesia, Jakarta.

Tambunan. 2013. Standar Operasional Prosedur. jakarta, PT Suku Buku

Rustiyanto. E. 2009. Etika Profesi Perekam Medis dan Informasi Kesehatan. Yogyakarta:Graha Ilmu

WHO, 2010. International Statistical Clasification of Deseases and Related Health Problem 10th Vol. 1, 2, 3 Second Edition Th. 2010 Ganeva. 